\title{
The functional morphology of the thymus - new views on this forgotten organ
}

\author{
Havrlentova $\mathrm{L}^{1,2}$, Holeczy $\mathrm{P}^{2}$, Gergisakova $\mathrm{H}^{3}$ \\ Institute of Histology and Embryology, Faculty of Medicine, Comenius University in Bratislava, Slovakia. \\ Lucia.Havrlentova@seznam.cz
}

Dear Editor-in-Chief, Bratislava Medical Journal,

We have been highly interested in the topical review "The role of ascorbic acid and monosodium glutamate in thymocyte apoptosis" from Serbian authors Pavlovic and Sarac (1). We congratulate the authors for their interest and actual paper on the one of the most mysterious organ of human body, the thymus. The aim of our paper is to shortly summarize the recent knowledge about factors affecting morphology of the thymus gland, especially focused on Slovak studies.

The thymus is lymphoepithelial organ with immune and endocrine functions. It is the crossroad between immune and neuroendocrine systems (2). Interactions between nervous, endocrine, and immune systems might represent the anatomical and functional basis for the understanding of the pathways and mechanisms that enable the brain to modulate the progression of disease (3). From the phylogenetical point of view, thymus played a key role in the evolution of animals during development of an adaptive immune system; therefore it is an important feature separating higher vertebrates from other animals (4). The development of thymus gland is extremely complex. The thymus is derived from pharyngeal region; a region from which, in case of aquatic vertebrates, the gills develop $(5,6)$. The development of the pharyngeal region, as well as its derivates (connective tissue, bones and muscles of head and neck, thymus, parathyroid and thyroid glands) involves the interactions between a numbers of disparate embryonic cell types derived from all germ layers: ectoderm (including neural crest-derived cells), endoderm, and mesoderm (7-9).

For centuries, thymus remained an enigmatic organ with unknown functions. The first demonstration of its crucial role in establishing the development of normal immune system was provided in 1961. It was shown that mice thymectomized immedi-

${ }^{1}$ Institute of Histology and Embryology, Faculty of Medicine, Comenius University in Bratislava, Slovakia, ${ }^{2}$ Department of Surgery, Vítkovice Hospital in Ostrava, Czech Republic, and ${ }^{3}$ Institute of Forensic Medicine, Faculty of Medicine, Comenius University in Bratislava, Slovakia

Address for correspondence: L. Havrlentova, MD, Department of Histology and Embryology, Faculty of Medicine, Comenius University in Bratislava, Sasinkova 4, SK-811 08 Bratislava, Slovakia.

Phone: +421.2 .59357284$ ately after birth had poorly developed lymphoid tissues, impaired immune responses and inordinate susceptibility to intercurrent infections (10-12).

Due to the knowledge of the normal development and microscopic structure, thymus gets a new importance this time. The human thymus is an organ, which interests specialists from many branches: theoretical and clinical. As a primary lymphoid organ and the place of maturation of T-lymfocyte subpopulation, thymus presents the biggest interest for immunologists. It's the only lymphatic organ, in which the epithelial cells form the carrying framework (13). That is predetermined by its incomparable properties, which are also reflected in many pathological states. Thymus develops from the interaction of all three germinal layers (14). During human ontogenesis, thymus undergoes major morphological changes including a rapid prenatal growth and postnatal progressive (age-related) involution (15).

Both radiologists and other clinicians interested in the neck region (for example 16-18) frequently get into touch with congenital development defects and remnant embryonal descent of thymus. Migration of the neural crest cells, which is also important for the development of heart, is closely connected to the ordinary development of thymus. For example, it brings up the question of congenital immunodeficiency by various heart defects (19), chromosomal anomalies such as the DiGeorge's syndrome (for example 20-23).

Based on the knowledge of thymic normogenesis, some authors question the prenatal diagnostic of congenital heart defects by examining the thymus by some acceptable, non-invasive imaging technology (24). The question of thymus transplantation in its congenital agenesis is becoming very actually at this place (25). The thymic size can be an important indicator of the function of immune system (26), nutrition status $(27,28)$, and also the general health status of child in the pediatric praxis $(29,30)$. In medical literature, some authors also expected the relationship between the thymic normogenesis and development of atopy or allergy (31, 32). The changes in T-lymphocyte population (on the cellular and molecular level) and thymus involution are also connected to the aging of the immune system. Early aging of the immune system can thereby contribute to the genesis of autoimmune disease and also expressively affect the overall ageing of the organism $(33,34)$. 
Human thymus reaches its biggest size in proportion to body weight at birth. Under normal circumstances, the thymus commences age-related involution soon after birth. The thymus undergoes a progressive reduction in size due to profound changes in its anatomy associated with the loss of thymic epithelial cells and decrease in thymopoiesis (35-37). Age-related involution is reversible. For example, castration in old rats and mice resulted in the regeneration of the atrophied thymuses $(38,39)$. In various stressful conditions, the thymus is subjected to stress-related involution. These progressive, but reversible processes take place within a few days of stress. This involution is intensive especially in newborns and infants who normally have a large volume of thymus tissue. An increased levels of endogen steroids (conspicuous according to Hans Selye theory by stress) causes atrophy of thymus cortex and thereby its preterm aging. Consequently, a special chapter of thymus studies is the research of factors influencing its function, whereas not all exogenous factors are known by now.

A chronic stress in the experiment (in laboratory rats evoked by cyclical and forced swimming) caused the reduction of the thymus volume, decreased the number of lymphocytes and simultaneously also increased the number of apoptotic lymphocytes in thymus (40).

Also, infections in pregnancy, for example chorioamnionitis, cause structural changes in thymus of fetus and newborn (41). De Felice et al (42) proved the reduction of thymus in newborns with chorioamnionitis by the X-ray studies of thorax. Their results affirmed the importance of prenatal examination of the size of thymus for precocious diagnostics and successful treatment of gravidity with chorioamnionitis. By a preterm ageing, thymus also reacts to common infections of the upper airways. Children of HIV-positive mothers had also small thymus (43). Some studies pointed out the connection between small thymus and children mortality. The size of this organ is in much closer relation with mortality than the birth weight (44).

In 1903, it was found out that infant thymus is sensitive to Xray irradiation. Bodey et al (45) described the experiment on dogs and mice, which were exposed to a single application of whole body irradiation. The so-called "thymic cysts" were found in the cortex of thymus. Their secretory product, probably thymic hormones, presented the components of micro-environment for developing thymocytes in the phase of an acute thymus involution.

Fatality in the Chernobyl Nuclear Power Plant (Ukraine) was one of the biggest radiation "experiments" in history. Dramatic reduction of the number of $\mathrm{CD} 3+\mathrm{CD} 4+$ a $\mathrm{CD} 5+\mathrm{CD} 8+$ lymphocytes, as well as thymosin $\alpha 1$ level in blood was noted in humans working within $30 \mathrm{~km}$ from nuclear accident (46).

Thymic size can also be affected by hormonal treatment. The impact of corticosteroids on the size of thymus has not been yet well examined. According to Fletcher et al (47), antenatal administration of exogenous steroids causes a significant reduction of the thymic size in premature infant. On the other hand, Chen et al (48) didn't find any statistically significant difference in the thymic size in newborn after antenatal therapy by dexamethazone.

Thymic size is very sensitive to chemotherapy; after chemotherapy of patient with malign disease, thymus volume has been reduced on the average by $43 \%$. Nevertheless, consequently between the first and the second chemotherapy thymus volume increased by $36 \%$ (49).

The influence of the nutrition on the size and function of thymus is also interesting, specially its particular components, eventually exogenous substances (for example pesticide, food dopes) received by food (1). For example, an absence of biotin in mice food affects not only the bone metabolism, but it also causes an early involution of thymus (50). From an ubiquitous environmental toxicants to negative influence on the thymic size thereby also on their function have, for example, bendiocarbamate (52) and polychlorinated biphenyls $(53,54)$.

Collinson et al (27) confirmed the relation between nutrition and the size of thymus in newborns. They found out that in Gambia, the size of newborns thymus was smaller in period between July till December - in months of so-called "hungry season". On the other hand, research of the thymus size by specific sub-population, Roma newborns living in Slovakia, hasn't shown any difference between the thymic sizes compared to majority (non-Roma) population (28). At the same time, if we take into consideration their nutrition deficient (for example they receive only $44 \%$ of the recommended daily dose of vitamin C), suboptimal hygienic norm, higher unemployment, lower education, more common occurrence of contagious diseases, higher ratio of smoker and alcohol consumers (55-58), we would expect markedly smaller thymus in the case of Roma people. Park et al (53) even discovered bigger thymus in Roma newborns in comparison to non-Roma population. However, they coudn't explain this difference.

Thymic involution and thus related variance of thymic function in children, conditional by virtue of external or internal factors, may have a diagnostic as well as therapeutic sense. It presents the acceleration of age-related involution of thymus. The consequence is an increase of apoptotic cells and inhibition of lymphopoesis. A fast decrease in the size of thymus leads to drop of its function. The exact mechanism of an early involution as well as the possible use of this knowledge in everyday clinical praxis has not been explored deeply enough by now (15).

\section{References}

1. Pavlovic V, Sarac M. The role of ascorbic acid and monosodium glutamate in thymocyte apoptosis. Bratisl Lek Listy 2010; 111 (6): 357-360.

2. Geenen V, Brilot F. Role of the thymus in the development of tolerance and autoimmunity towards the neuroendocrine system. Ann N Y Acad Sci 2003; 992: 186-195.

3. Mravec B, Ondicova K, Valaskova Z, Gidron Y, Hulin I. Neurobiological principles in the etiopathogenesis of disease: when diseases have a head. Med Sci Monit 2009; 15 (1): RA6-16.

4. Bowden TJ, Cook P, Rombout JH. Development and function of the thymus in teleosts. Fish Shellfish Immunol 2005; 19 (5): 413-427.

5. Varga I, Pospí̌ilová V, Gmitterová K, Gálfiová P, Polák Š, Galbavý $\breve{\text { S}}$. The phylogenesis and ontogenesis of the human pharyngeal region focused on the thymus, parathyroid, and thyroid glands. Neuroendocrinol Lett 2008; 29 (6): 837-845. 
6. Pospíšilová V, Slípka J. Pharyngeal region derivates in early human development. Plzeň lék Sborn 2000; 74: 93-98.

7. Graham A. Development of the pharyngeal arches. Am J Med Gen 2003; 119A (3): 251-256.

8. Graham A. The development and evolution of the pharyngeal arches. J Anat 2001; 199: 133-141.

9. Varga I, Pospisilova V, Jablonska-Mestanova V, Galfiova P, Polak S. The thymus: picture review of human thymus prenatal development. Bratisl Lek Listy 2011; 112 (7): 368-376.

10. Miller JF. Immunological function of the thymus. Lancet 1961; 2 : 748-749.

11. Miller JFAP. The discovery of thymus function and of thymus-derived lymphocytes. Immunol Rev 2002; 185: 7-14.

12. Miller JFAP. Events that led to the discovery of T-cell development and function - a personal recollection. Tissue Antigens 2004; 63: 509-517.

13. Schuurman HJ, Kuper CF, Kendall MD. Thymic microenviroment at the light microscopic level. Microsc Res Tech 1997; 38: 216-226.

14. Varga I, Jablonska V, Cingel V, Kubikova E, Dorko F, Polak S. The first histological and immunohistochemical examination of thymus in case of fetus in fetu. Ann Anatomy 2010; 192: 232-236.

15. Varga I, Uhrinova A, Toth F, Mistinova J. Assessment of the thymic morphometry using ultrasound in full-term newborns. Surg Radiol Anat 2011; 33 (8): 689-695.

16. Bistritzer T, Tamir A, Oland J, Varsano D, Manor A, Gall R, Aladjem M. Severe dyspnea and dysphagia resulting from an aberrant cervical thymus. Eur J Pediatr 1985; 144: 86-87.

17. Conwell LS, Batch JA. Aberrant cervical thymus mimicking a cervical mass. J Paediatr Child Health 2004; 40: 579-580.

18. Pai I, Hegde V, Wilson POG, Ancliff P, Ramsay AD, Daya H. Ectopic thymus presenting as a subglottic mass: diagnostic and management dilemmas. Int J Ped Otorhinolaryngol 2005; 69: 573-576.

19. Varga I, Pospisilova V, Jablonska V, Sisovsky V, Galfiova P, Polak S, Adamkov M. Thymic Hassall's bodies of children with congenital heart defects. Bratisl Lek Listy 2010; 111 (10): 552-557.

20. Müller W, Peter HH, Wilken M, Jüppner H, Kallfelz HC, Krohn HP, Miller K, Rieger CHL. The DiGeorge syndrome. Clinical evaluation and course of partial and complete forms of the syndrome. Eur J Pediatr 1988; 147: 496-502.

21. Levy-Mozziconacci A, Wernert F, Scambler P, Rouault F, Metras D, Kreitman B, Depetris D, Mattei MG, Philip N. Clinical and molecular study of DiGeorge sequence. Eur J Pediatr 1994; 153: 813-820.

22. Scambler PJ. The 22q11 deletion syndromes. Hum Mol Genet 2000; 9 (16): 2421-2426.

23. Cancrini C, Romiti ML, Finocchi A, Di Cesare S, Ciaffi P, Capponi C, Pahwa S, Rossi P. Post-natal ontogenesis of the T-cell receptor CD4 and $\mathrm{CD} 8 \mathrm{~V} \beta$ repertoire and immune function in children with DiGeorge syndrome. J Clin Immunol 2005; 25 (3): 265-274.

24. Chaoui R, Kalache KD, Heling KS, Tennstedt C, Bommer C, Korner H.Absent or hypoplastic thymus on ultrasound: a marker for deletion $22 \mathrm{q} 11.2$ in fetal cardiac defects. Ultrasound Obstet Gynecol 2002; 20: 546-552.

25. Markert ML, Alexieff MJ, Li J, Sarzotti M, Ozaki DA, Devlin BH, Sedlak DA, Sempowski GD, Hale LP, Rice HE, Mahaffey SM, Skinner MA. Postnatal thymus transplantation with immunosuppression as treatment for DiGeorge syndrome. Blood 2004; 104 (8): 2574-2581.
26. Jeppesen DL. The size of the thymus: an important immunological diagnostic tool? Acta Pædiatr 2003; 92: 994-995.

27. Collinson AC, Moore SE, Cole TJ, Prentice AM. Birth season and environmental influences on patterns of thymic growth in rural Gambian infants. Acta Pædiatr 2003; 92: 1014-1020.

28. Varga I, Tóth F, Uhrinová A, Neščáková E, Pospíšilová V, Polák S. Anthropometry, nutrition status and thymic size of Gypsy newborns from Southwestern Slovakia. Bratisl Lek Listy 2009; 110 (6): 354-357.

29. Aaby P, Marx C, Traunner S, Rudaa D, Hasselbalch H, Jensen H, Lisse I. Thymus size at birth is associated with infant mortality: a community study from Guinea-Bissau. Acta Pædiatr 2002; 91: 698-703.

30. Varga I, Tóth F, Uhrinová A, Neščáková E, Polák Š. Association among size of thymus, anthropometric dimensions and number of lymphocytes in peripheral blood in newborns from Slovakia. Biomed Pap Med Fac Univ Palacky Olomouc Czech Repub 2009; 153 (3): 229-234.

31. Godfrey KM, Barker DJ, Osmond C. Disproportionate fetal growth and raised IgE concentration in adult life. Clin Exp Allergy 1994; 24 (7): 641-648

32. Benn CS, Jeppesen DL, Hasselbalch H, Olesen AB, Nielsen J, Björkstén B, Lisse I, Aaby P. Thymus size and head circumference at birth and the development of allergic diseases. Clin ExpAllergy 2001;31: 1862-1866.

33. Prelog M. Aging of the immune system: a risk factor for autoimmunity? Autoimmun Rev 2006; 5 (2): 136-139.

34. Varga I, Pospíšilová V, Tóth F, Bevízová K, Polák Š. Faktory ovplyvňujúce vel'kost' a involúciu týmusu detí. (Article in Slovak, Factors affecting children thymus size and involution). Čes-slov Pediat 2008; 63 (4): 194-200.

35. Domínguez-Gerpe L, Rey-Méndez M. Evolution of the thymus size in response to physiological and random events throughout life. Microse Res Tech 2003; 62: 464-476.

36. Taub DD, Longo DL. Insights into thymic aging and regeneration. Immunol Rev 2005; 205: 72-93.

37. Weerkamp F, De Haas EFE, Naber BAE, Comans-Bitter WM, Bogers AJJC, van Dongen JJM, Staal FJT. Age related changes in cellular composition of the thymus in children. J Allergy Clin Immunol 2005; 115 (4): 834-840.

38. Dorko F, Kluchova D, Bolekova A, Spakovska T, Borosova T, Lovasova $\mathrm{K}$. Influence of surgical and chemical orchiectomy on weight and distribution of AChE-nerve fibres in thymuses of adult rats. Eur J Histochem 2011; 55 (3): e22.

39. Heng TS, Goldberg GL, Gray DH, Sutherland JS, Chidgey AP, Boyd RL. Effects of castration on thymocyte development in two different models of thymic involution. J Immunol 2005; 175 (5): 2982-2993.

40. Živkovič IR, Rakin AK, Petrovič-Djergoič DM, Kosec DJ, Mičič V. Exposure to forced swim stress alters morphofunctional characteristics of the rat thymus. J Neuroimunol 2005; 160: 77-86.

41. Toti P, De Felice C, Stumpo M, Schürfeld K, Di Leo L, Vatti R, Bianciardi G, Buonocore G, Seemayer TA, Luzi P. Acute thymic involution in fetuses and neonates with chorioamnionitis. Hum Pathol 2000; 31 (9): 1121-1128.

42. De Felice C, Latini G, Toti P, D'Addario V, Petraglia F, Bagnoli F. Small thymus at birth and gestational age. Eur J Pediatr 2002; 161: 362-363.

43. Jeppesen D, Hasselbalch H, Ersbøll AK, Heilmann C, Valerius NH. Thymic size in uninfected infants born to HIV-positive mothers and fed with pasteurized human milk. Acta Pædiatr 2003; 92: 679-683. 
44. Aaby P, Marx C, Traunner S, Rudaa D, Hasselbalch H, Jensen H, Lisse I. Thymus size at birth is associated with infant mortality: a community study from Guinea-Bissau. Acta Pædiatr 2002; 91: 698-703.

45. Bodey B, Bodey B Jr, Siegel S, Keiser HE. Involution of the mammalian thymus, one of the leading regulators of aging. In Vivo 1997; 11: $421-440$.

46. Titova LD, Yarilin AA, Sharova NI, Oradovskaya IV. The quantitatives of T- cell subpopulation and level of alpha1-thymosin and autoantibodies reacting with thymic epithelium in serum of persons, who worked in 30-km zone of Chernobyl atomic electronic station. Radiatzion Biol Radioekol 1996; 36: 601-609.

47. Fletcher BD, Masson MM, Lisbona A, Riggs T, Papageorgiou AN. Thymic response to endogenous and exogenous steroids in premature newborn infants. J Pediatr 1979; 95: 111-114.

48. Chen CM, Yu KY, Lin HC, Yeh GC, Hu HH. Thymus size and its relationship to perinatal events. Acta Pædiatr 2000; 89: 975-978.

49. Choyke PL, Zeman RK, Gootenberg JE, Greenberg JN, Hoffer F, Frank JA. Thymic atrophy and regrowth in response to chemotherapy: CT evaluation. Am J Roentgenol 1987; 149: 269-272.

50. Báez-Saldaña A, Ortega E. Biotin deficiency blocks thymocyte maturation, accelerates thymus involution, and decrease nose-rump length in mice. J Nutr 2004; 134 (8): 1970-1977.

51. Pallaro AN, Roux ME, Slobodianik NH. Nutrition disorders and immunologic parameters: study of the thymus growth in growing rats. Nutrition 2001; 17 (11-12): 972-973.
52. Dorko F, Danko J, Flesarova S, Boros E, Sobekova A. Effect of pesticide bendiocarbamate on distribution of acetylcholine- and butyrylcholinepositive nerves in rabbits's thymus. Eur J Histochem 2011; 55 (4): e37.

53. Park HY, Hertz-Picciotto I, Petrik J, Palkovicova L, Kocan A, Trnovec T. Prenatal PCB exposure and thymus size at birth in neonates in Eastern Slovakia. Environ Health Perspect 2008; 116: 104-109.

54. Hertz-Picciotto I, Park HY, Dostal M, Kocan A, Trnovec T, Sram R. Prenatal exposures to persistent and non-persistent organic compounds and effects on immune system development. Basic Clin Pharmacol Toxicol 2008; 102 (2): 146-154.

55. Hajioff S, McKee M. The health of the Roma people: a review of the published literature. J Epidemiol Community Health 2000; 54: 864-869.

56. Ginter E, Krajcovicova-Kudlacova M, Kacala O, Kovacic V, Valachovicova M. Health status of Romanies (Gypsies) in the Slovak Republic and in the neighboring countries. Bratisl Lek Listy 2001; 102 (10): 479-484.

57. Krajcovicova-Kudlackova M, Blazicek P, Spustova V, Valachovicova M, Ginter E. Cardiovascular risk factors in young Gypsy population. Bratisl Lek Listy 2004; 105 (7-8): 256-259.

58. Szabová E, Neščáková E, Zeljenková D, Kudláčková M, Varga I, Ginter E. et al. Overview of the biological and health profile of the Romanies in western Slovakia. 189-203. In: Abreau L, Sandor J (Eds). Monitoring health status of vulnerable groups in Europe: past and present. Pecs; Pecs University Faculty of Health sciences, 2006.

Received October 18, 2010. Accepted December 13, 2011. 